\title{
Gulnara Aghalarova
}

Azerbaijan International Development Agency

Ministry of Foreign Affairs of Azerbaijan

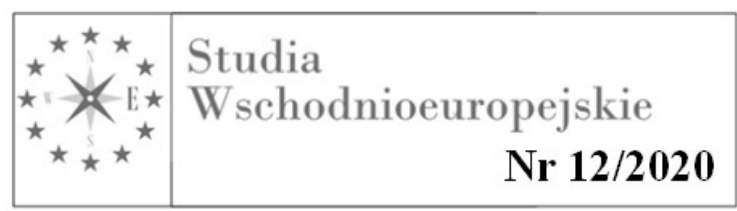

\section{Azerbaijan's cultural diplomacy: at the service of national interests}

$\mathrm{C}$

ultural diplomacy is one of the tools of the state foreign policy that helps to build and strengthen bridges of friendship between countries and peoples and provide them with new opportunities for establishing good neighborly relations through a variety of forms of cultural exchange, search and finding ways for mutual understanding.

The term "cultural diplomacy" first appeared in the thirties of the last century and was coined by the American researcher Frederick C. Barghoorn. He defined this type of diplomacy as the "manipulation of cultural materials and personnel for propaganda purposes", which implies an ideologized subtext, a hidden meaning imposed due to the situation and specific policies of that time states. However, years later, since cultural diplomacy has been actively used by many Western countries, the term received a positive interpretation, meaning the development of cultural ties and their use in international relations for the improvement of mutual understanding between countries.

Almost thirty years later, in 1967, at a UNESCO round table in Monaco, the term "cultural policy", used for the first time, was given the following definition: "Cultural policy is a body of principles, administrative and financial activities and procedures which provide the basis for state activities in the field of culture ".

Cultural diplomacy is an important part of the soft power policy, which includes the exchange of ideas, information, works of art and other components of culture between states and peoples, and its task is to strengthen relations, promote national interests, and achieve national security goals. It helps to better understand foreign people and thereby, promote mutual understanding. Cultural diplomacy contributes to the formation of the country's image abroad, using the entire arsenal of national culture: art, exhibitions, educational programs, the exchange of various achievements, etc.

Cultural diplomacy has in its arsenal many of the most diverse forms and methods of promoting national culture. This activity can also be correlated with public diplomacy. This term first appeared in 1990 in an article by Joseph Nye, an American political scientist who called public diplomacy an important tool in disseminating information about the sources of a nation's "soft power". Among entities using "soft power", thus contributing to the creation an attractive image of their nation, he named non-governmental organizations and foundations.

Now in the turbulent conditions of a series of conflicts and local wars arising in various parts of the world threatening to provoke another global war, cultural diplomacy more than ever becomes an important foreign policy resource, an effective tool that could have a positive impact on minds and hearts of people. Undoubtedly, without cultural diplomacy it is 
impossible to popularize the cultural heritage of any country or the achievements of any people. Cultural diplomacy possesses great capacity and potential for creating a positive image of the country, the use of which depends only on the professionalism of those people who work in this field. Therefore, it is quite natural that the cultural factor has acquired a new meaning in international politics, and states have begun to pay great attention to it.

It is well known that the founder of diplomatic norms and rules is France. Starting from the 19th century, diplomats of France have made and continue to contribute greatly to the dissemination of cultural values of their country outside its borders. The cultural diplomacy development of this European country has gone through several phases. Now it is carried out with a clearly developed policy in the context of globalization, media development and technologization. The public organization L'Alliance française, founded in 1883, has been conducting this work for a considerably long time. Today this organization has its representative offices in 146 countries of the world, where it operates with the support of the French embassies.

\section{Azerbaijan's approach to cultural diplomacy}

As a result of reasonable implementation of its cultural diplomacy, Azerbaijan, that rather recently became independent, has gained respect as a country with a highly developed culture, a country that is endowed with great potential and has much to offer to the world. Being active in the field of cultural diplomacy, our country has achieved significant success in this area and has proved that it is a state, striving for mutual cultural enrichment of world nations, contributing rapprochement of peoples on the basis of universal spiritual values and mutual understanding.

Dissemination of the national cultural heritage in the world and promotion of cultural exchanges are among foreign policy priorities of Azerbaijan at a new phase of its development. The effectiveness of Azerbaijan's cultural diplomacy is particularly evident in the work of the Heydar Aliyev Foundation headed by Azerbaijan's First Vice President, UNESCO and ISESCO Goodwill Ambassador Mehriban Aliyeva.

For many years, since the year of its establishment in 2004, the promotion of the cultural heritage of Azerbaijan - one of the Foundation's goals it was created for- has been most skillfully and creatively implemented under her leadership. Over the past years, the Foundation has already implemented many grand projects requiring an integrated approach.

Thus, the QARABAĞ XANONDӘLORİ album was presented at the annual meeting of goodwill ambassadors at UNESCO Headquarters in 2005. One of the objectives of this project - as Mehriban Aliyeva said in her speech on that occasion - was to bring "the pain of the Garabagh land, the just cause of Azerbaijan" to the attention of the whole world. The same year 5 booklets were published under the general title "The True Facts about Garabagh", which are as follows: "Brief information of the history of Garabagh", "The beginning of the Garabagh conflict", "The Khojaly genocide", "Activity of Armenian terrorist organizations against Azerbaijan", "Consequences of Armenian aggression against Azerbaijan". In 2007, the foundation, in association with the Ministry of Foreign Affairs of Azerbaijan, published the book entitled "WAR AGAINST AZERBAIJAN: TARGETING CULTURAL HERITAGE". The book includes a multimedia disk and a DVD with a documentary film. 
Notably, Azerbaijan's determined efforts to convey true information about the rich cultural heritage of Garabagh as one of the most important historical areas that contributed to the forging of the Azerbaijani people's identity have been successful.

We've also managed to draw the attention of the world community to the fact that the most valuable cultural and historical sites, archaeological and architectural monuments, including ancient and early medieval burials, the Christian heritage of Caucasian Albania and the masterpieces of Muslim architecture, as well as natural monuments in the occupied territories are exposed to a number of dangers like total demolition and destruction, targeted changes made to them in order to falsify their true nationality, looting of antiquities, etc. Thanks to all this activity, we've been able not only to dispel lies about history used as an ideological basis for the Armenian aggression against Azerbaijan, but we also have ensured that protection and preservation of the cultural heritage of Garabagh, Syrian Palmyra and the monuments of Mesopotamia should equally be the matter of concern of the world community.

Modern world terms stipulate that presence of a country in the information space determines the degree of its visibility on the cultural map of the world and success in promoting truthful information about it, which is crucial in the case of Azerbaijan.

Moreover, we not only respond to the challenges associated with the cultural challenges posed by the conflict, but also quite successfully form a new positive cultural environment as a means of positioning Azerbaijan in the world.

As a result of our efforts, in 2008, UNESCO declared the Azerbaijani mugham one of the masterpieces of the oral and intangible cultural heritage of humankind. Subsequently, in 10 years, another 13 cultural elements were inscribed in the UNESCO list of masterpieces of the oral and intangible cultural heritage of humankind through 2018. They are as follows:

- Azerbaijani mugham (2008);

- The Art of Azerbaijani Ashiq (2009);

- Traditional art of Azerbaijani carpet weaving in the Republic of Azerbaijan (2010);

- Craftsmanship and performance art of the Tar, a long-necked string musical instrument (2012);

- Chovqan, a traditional Karabakh horse-riding game in the Republic of Azerbaijan (2013);

- Traditional art and symbolism of Kelaghayi, making and wearing women's silk headscarves (2014);

- Copper craftsmanship of Lahij (2015);

- Flatbread making and sharing culture: Lavash (2016);

- Novruz (2016);

- Art of crafting and playing with Kamancha, a bowed string musical instrument (2017);

- Dolma making and sharing tradition, a marker of cultural identity (2017);

- Heritage of Dede Qorqud (2018);

- Yalli, traditional group dances of Nakhchivan (2018).

Over the past decade, Azerbaijan has become a truly bright star on the global map of cultural festivals and humanitarian forums. A vivid example of this is Gabala International Music 
Festival that has featured international contest of young pianists, concerts of mugham, as well classic, chamber, jazz and vocal music since 2009. The same year, the tradition of holding the world's first International Mugham Festival was established and performers of this original genre, as well as traditional oriental modes close to it, performed together on the same stage. This world scale unique festival, held 2-3 times a year, is accompanied by "The World of Mugham" international scientific symposia, thereby significantly contributing to the theoretical study of music traditions of the East as integrated part of the world treasury of music.

In 2008, the RA President Heydar Aliyev initiated Baku forum series which have become iconic cultural platform for discussing challenges of today's humanitarian development agenda. Since then 5 World Intercultural Dialogue Forums have been held in Baku. The keynote of these forums is tolerance, mutual respect, communication and cooperation of different cultures and civilizations for global sustainable development.

An important tool in promoting positive image of the Land of Fire and one of many priorities of Azerbaijan's foreign policy, along with significant cultural and humanitarian events held within the country, is increased presence of our cultural actors in the capitals of the leading countries, where the Cultural Centers of Azerbaijan have been gradually opening.

Sponsored by Heydar Aliyev Foundation and Ms. Arzu Aliyeva, the "Eternal Business Trip" documentary of 2016 and "Ali and Nino" feature film based on the novel by Gurban Sayid (the world premiere of it took place the same year) proved to be the effective way of delivering information about the Democratic Republic of Azerbaijan, the first democratic state in the Muslim world, to the modern world audience.

All of the above reflects only some, perhaps the most striking aspects of the protection of the cultural heritage of Azerbaijan. In this regard, I would like to highlight the multidimensional activities of the First Vice President of the Heydar Aliyev Foundation, Ms. Leyla Aliyeva. This includes her activities as general coordinator on Intercultural Dialogue of the Organization of Islamic Cooperation Youth Forum and her chairmanship in the AYOR, the most active youth organization outside Azerbaijan, as well as her activities as FAO Goodwill Ambassador.

It is equally important to acknowledge her role in a number of projects which she initiated, such as, the Fly to Baku exhibition of contemporary art of Azerbaijan, which has received an overwhelming response in all major European capitals and cultural centers from London to Moscow, and the publication of the Baku magazine in Russian and English, and other interesting activities in the area of intercultural communication.

Art lovers, youth, and just ordinary people in various countries all over the world open a window to Azerbaijan, get the opportunity to become acquainted with ancient traditions and dynamic nature of the modern life in the Land of Fire through this kind of activity.

Many of them visit Azerbaijan as tourists and continue to take an interest in it when they return home. If it's not cultural diplomacy, then what is it?

It is well recognized that winning people's favor is one of the main tasks of the art of diplomacy. And what could better contribute to achieving this goal than making friends through culture and art. Fortunately, Azerbaijan was able, in a fairly short period from the historical point of view, to create its own image, recognizable in the global space of cultural relations. Peerlessly represented by state top officials, this image has become one of the most 
important components of the "soft power" of Azerbaijan, without which no country can successfully develop in the post-industrial world today.

\section{Streszczenie:}

W artykule omówiono znaczenie i globalne doświadczenia realizacji dyplomacji na rzecz kultury. Dyplomacja na rzecz kultury jest jednym z narzędzi polityki zagranicznej państwa, który pomaga budować i umacniać więzi między krajami i narodami oraz dawać im nowe możliwości nawiązywania dobrych stosunków sąsiedzkich poprzez różne formy wymiany kulturalnej, poszukiwania i znajdowania sposobów na wzajemne zrozumienie. Koncentruje się także na podejściu Azerbejdżanu do dyplomacji na rzecz kultury we współczesnym świecie oraz na atrakcyjności "miękkiej siły" w Azerbejdżanie, która staje się kluczowym czynnikiem oddziaływania na społeczeństwo w kraju. Upowszechnianie narodowego dziedzictwa kulturowego na świecie oraz promocja wymiany kulturalnej należą do priorytetów polityki zagranicznej Azerbejdżanu w nowej fazie jego rozwoju. Skuteczność dyplomacji kulturalnej Azerbejdżanu jest szczególnie widoczna w pracach Fundacji Heydar Aliyev, na czele której stoi pierwszy wiceprezydent Azerbejdżanu, UNESCO oraz ambasador dobrej woli ISESCO Mehriban Aliyeva.

\section{Słowa kluczowe:}

Azerbejdżan, dyplomacja kulturowa, UNESCO, soft power, wielokulturowość.

\section{Key words:}

Azerbaijan, cultural diplomacy, UNESCO, soft power, multicultural.

\section{Bibilografia:}

1. I. Prokofieva, Cultural diplomacy opportuninies for resolving a conflict. Second Cultural Diplomacy Forum of Ukraine, Diplomatic Academy of Ukraine. April 27, 2016.

2. Е. В. Василенко, Культурная дипломатия как инструмент «мягкой силы» государства [Cultural diplomacy as "soft power" instrument of the state]. Electronic journal. 2016, №1(5), pp. 68-80.

3. О.Лебедева, Культурная дипломатия как инструмент внешней политики России на современном этапе [Cultural diplomacy as instrument of the Russian foreign policy in modern period]. Международная жизнь, 2016, №9, pp. 76-84.

4. James Miles Carey, Cultural Diplomacy. 18 SEP 2018.

5. Культурная дипломатия и внешняя политика [Cultural Diplomacy and Foreign Policy]. https://news.day.az/

6. Культурная дипломатия Мехрибан Алиевой: что она сделала для Азербайджана и мира [Mehriban Aliyeva's cultural diplomacy: what has she done for Azerbaijan and the world]. Вестник Кавказа, 21 FEB 2017. 
7. Э. Макаревич, Привлекательность мягкой силы и способы ее измерения [Attraction of soft power and method of its measurement]. https://cyberleninka.ru/article/n/privlekatelnost-myagkoy-sily-i-sposoby-eeizmereniya/viewer 